\title{
Sustainability, Innovation, and Entrepreneurship: A Research with Administration and Secretariat Students
}

\author{
Luis Eduardo Brandão Paiva1, Tereza Cristina Batista de Lima², Evangelina da Silva \\ Sousa ${ }^{3}$, Emiliano Sousa Pontes 4
}

${ }^{1}$ Universidade Federal do Ceará - edubrandas@gmail.com

${ }^{2}$ Universidade Federal do Ceará - tcblima@uol.com.br

3 Universidade Federal do Ceará - evangelinasousa@gmail.com

4 Universidade Federal do Ceará - emilianopontes@alu.ufc.br

\section{KEYWORDS}

Administration, Innovative Sustainable

Behavior, Behavior, Entrepreneurial Intention, Executive Secretariat.

Received 09.01.2019

Reviewed 05.04.2019

Accepted 08.07.2019
ABSTRACT

This study analyzes the influence of sustainable and innovative behavioral constructs on the entrepreneurial intentions of university students. The investigated students were from the Administration and Executive Secretariat undergraduate programs. The influence on entrepreneurial intention by other entrepreneurs in the family or due to gender was also investigated. This is a descriptive research project of a quantitative nature. A sample of 429 students from a public university was obtained, in which 285 students were from the Administration program and 144 students were from the Executive Secretariat program. Various data analysis techniques were used for the treatment of data, including factorial analysis and logistic regression. The results indicated that sustainable and innovative behaviors influence the entrepreneurial intention of students in both the Administration and Executive Secretariat programs. In addition, entrepreneurs in the family strongly influenced the entrepreneurial intention of these individuals. There was also a gender influence on the entrepreneurial intention: for students from the Administration program, men appeared to be more prone to entrepreneurship than women, but this was not present among Executive Secretariat students. This study also contributes to the promotion of policies and practices at Higher Education Institutions (HEIs), because entrepreneurial intention is at present relevant. It is expected that HEIs incorporate sustainable and innovative social studies and practices to foster social and environmental benefits aligned with entrepreneurship.

\section{RESUMO}

Este estudo tem como objetivo analisar a influência dos constructos comportamentais sustentáveis e inovadores na intenção empreendedora dos universitários dos cursos de Administração e Secretariado Executivo. Adicionalmente, busca-se investigar a influência do gênero e dos familiares empreendedores na intenção empreendedora. Trata-se de uma pesquisa descritiva, de natureza quantitativa, em que se obteve uma amostra de 429 estudantes de uma universidade pública, sendo 285 do curso de Administração e 144 do curso de Secretariado Executivo. Para o tratamento dos dados, utilizaram-se técnicas de análise multivariada de dados, como a análise fatorial e a regressão logística. Os resultados apontaram que o comportamento sustentável e inovador exerce influência na intenção empreendedora dos estudantes dos cursos de Administração e Secretariado Executivo. Ademais, os familiares empreendedores influenciam fortemente na intenção empreendedora desses indivíduos. Para o curso de administração, houve influência do gênero (homens) na intenção empreendedora, mostrando-se que os homens estão mais propensos ao empreendedorismo do que as mulheres, fato não elucidado para os estudantes do curso de Secretariado Executivo. Como a intenção empreendedora é relevante na atualidade, este estudo visa contribuir para fomentar o incentivo de políticas e práticas direcionadas às Instituições de Ensino Superior (IES), com a expectativa de que as IES possam incorporar estudos e práticas ambientais, inovadoras e sociais alinhadas ao empreendedorismo - a fim de potencializar benefícios sociais e ambientais gerados pelos empreendedores. 


\section{Introduction}

Entrepreneurship is characterized as an attempt by the individual to create a new business or to expand an existing one (Liñán \& Chen, 2009). Innovation is considered an essential prerequisite for the creation of new employment opportunities and labor market insertion, as well as for stimulating economic development (Pauceanu, Alpenidze, Edu, \& Zaharia, 2019; Solhi \& Koshkaki, 2016).

Innovation is one of the dimensions related to entrepreneurship (Damanpour, 1991) and denotes an organization's tendency to support new ideas and changes and to enable the development of creative methods that can result in new processes, products, and/or services (Lumpkin \& Dess, 1996; Subotic, Maric, Mitrovic, \& Mesko, 2018). This has an impact on economic, social, and environmental development, and it is also essential to highlight the actions of entrepreneurs to achieve such impacts (Elkington, 2013; Subotic et al., 2018).

Entrepreneurial and innovative behaviors are recognized as key skills for the development of competitive strategies that can stimulate entrepreneurs to address changes and market challenges to improve organizational performance and competitiveness (Turunç, Türköz, Akkoç, \& Çaliskan, 2013). These behaviors are related to cognitive social process, and it is fundamental to understand how the entrepreneur perceives the environment through his actions (Turunç et al., 2013) using an integrated socio-psychological approach that incorporates models of how the entrepreneur responds to this experience (Walley \& Taylor, 2002).

Entrepreneurship is therefore a process that can be measured through intentions, activities, and interactions between individuals (Pauceanu et al., 2019). Esfandiar, Sharifi-Tehrani, Pratt, and Altinay (2019) point out the need to understand the origin of the intentions of potential entrepreneurs, as well as the factors that stimulate entrepreneurship given the cognitive state of entrepreneurial intention (EI) that directs the individual to the formation/creation of their own business.

Entrepreneurial intent constitutes a direction for future action (Moriano, Gorgievski, Laguna, Stephan, \& Zarafshani, 2012), because it is defined as the conscious mental state that precedes the action and directs attention to the purpose of initiating a new business (Krueger \& Carsrud, 1993), it is a precursor and directly related to entrepreneurial behavior (Ajzen, 1991; Fayolle \& Liñán, 2014).

Baron and Shane (2007) consider the literature on EI crucial to understanding aspects of entrepreneurship, emphasizing the importance of designing cognitive variables (way of interpreting knowledge) for the EI process. It is pertinent to evaluate whether people who intend to start a business are innovative and original in decisionmaking and idea generation (Kirton, 1976; Marcati, Guido, \& Peluso, 2008; Paiva, Lima, Rebouças, Ferreira, \& Fontenele, 2018), as innovative individuals can contribute directly to the development of new ideas and, consequently, to the creation of jobs (Shinnar, Giacomin, \& Janssen, 2012).

In addition, aligning environmental sustainability with entrepreneurship involves a decision-making process in which entrepreneurs should jointly consider the social, environmental, and economic implications of their business activities (Muñoz, 2018), because, when they are geared towards sustainable development, they are not based on the "triple bottom line" (Elkington, 1997; 2013). Entrepreneurship with a focus on sustainable development is associated with more traditional concepts of entrepreneurship (Kuckertz \& Wagner, 2010), but also has the additional potential to help society and the environment (Parrish, 2008; Silveira, Backes, \& Kobayashi, 2017; Tilley \& Parrish, 2009), pointing to an alignment between sustainability (with an environmental focus) and entrepreneurship (in the face of EI).

The European Commission (2013) has suggested that levels of entrepreneurship can be affected by education, particularly entrepreneurship-oriented higher education courses, which are the most likely to form entrepreneurs or people with EIs (Verheul, Wennekers, Audretsch, \& Thurik, 2001). In this sense, Pauceanu, Alpenidze, Edu, and Zaharia (2019) emphasize the importance of universities in stimulating the formation of the entrepreneurial spirit, indicating an action favorable to entrepreneurship so that they develop into consolidated businesses, which can generate employment and income, with positive impacts on the economy, society, and the environment. 
Considering the discussions and taking into account that the target population of this study is composed of Brazilian university students in the courses of Administration and Executive Secretariat, it can be emphasized that the Administration course, in accordance with the evidence of Paço, Ferreira, Raposo, Rodrigues, and Dinis (2011), develops research and practices focused on entrepreneurship, while the Executive Secretariat presents entrepreneurship as one of its specific training lines for the profession (Resolution 3, 2005), and this potentiates the development of entrepreneurial characteristics during the training of these students (Barbosa \& Durante, 2013).

Schmidt et al. (2008) have pointed out that students in Administration and Executive Secretariat courses demonstrate entrepreneurial characteristics such as commitment, the pursuit of opportunities, initiative, independence, selfconfidence, and persistence that foster innovative ideas, and they are also developers of sustainable entrepreneurial action strategies. It is worth noting that the level of EI can be influenced by other factors, including gender, entrepreneurial family, nationality, and educational level (Arregle et al., 2015; Paiva et al., 2018; Rico \& Cabrer-Borrás, 2018; Sieger \& Minola, 2017; Wang \& Wong, 2004).

From this, the following guiding question emerged for this study: what sustainable and innovative behavioral constructs influence the EI of university students? Faced with this questioning, this study analyzes the influence of sustainable and innovative behavioral constructs on EI. Additionally, the influence of gender and the family entrepreneurs in the EI are also investigated.

For this purpose, a questionnaire was given to undergraduate students of the Administration and Executive Secretariat courses. The results suggest that there is a positive influence of sustainable and innovative behavioral constructs and the family entrepreneurs on the EI of the university students in both of the courses investigated. Regarding gender, statistical significance was only found for students in the Administration course, where male students were more likely to demonstrate EI.

From the theoretical-empirical perspective, this research is relevant for aligning sustainable and innovative behavioral constructs with the EI of university students, because the insertion of the environmental variable in the educational and entrepreneurial contexts hints at possible changes in society's expectations in terms of the recognition and use of opportunities. In addition, the research results can also stimulate the formulation of entrepreneurial education programs aimed at students from the most diverse areas of knowledge, which could encourage EIs and behaviors and have a direct impact on the economy, society, and the environment.

In this way, this research seeks to broaden the empirical and conceptual literature on entrepreneurship, because empirical research with a specific focus on environmental sustainability in the understanding of EI or behavior is still in its early stages. This alignment between innovation, entrepreneurship, and sustainability contributes to the construction of scientific knowledge related to the Applied Social Sciences, especially to Management, giving an innovative perspective to this study.

\section{Theoretical Framework}

\subsection{Sustainable Behavior}

Sustainable behavior refers to studies that are in the interest of environmental research (CorralVerdugo \& Pinheiro, 1999; Günther, Pinheiro, \& Guzzo, 2004) and carry elements of future orientations, because it requires optimization of the consequences of the environmental, social and economic needs of the present to meet the needs of future generations (Van der Wal, Van Horen, \& Grinstein, 2018). Studies related to environmental aspects are relatively recent, making it possible to contribute to a multidisciplinary and transdisciplinary field, which challenges researchers through multiple and diverse approaches (Hutchison, 2018; Pato \& Tamayo, 2006).

There has been a large growth in academic research regarding environmental issues that seek to identify the profile of the individual considered ecologically or environmentally conscious, but demographic variables alone are not enough to investigate this profile, making a broader characterization necessary to measure behavior (Günther et al., 2004; Straughan \& Roberts, 1999), as well as investigations into concerns about consumption, waste, water, and the domestic

Revista de Negócios, v. 24, n. 3, p. 7-26, July, 2019. 
environment (Gonçalves-Dias, Teodósio, Carvalho, \& Silva, 2009).

Research on sustainable behavior is characterized by the observation and understanding of actions that may directly affect the environment (Corral-Verdugo, 2012; Fischer, Mauer, \& Brettel, 2018; Kaiser, Doka, Hofstetter, \& Ranney, 2003) such as composting, the use of alternative means of transportation, and the acquisition of energyefficient appliances, because there is no commitment on the part of all individuals to develop this behavior (Minton, Spielmann, Kahle, \& Kim, 2018).

However, Corral-Verdudo (2012) considers sustainable behavior to be more of a negative than positive effect in relation to individual attitudes and behaviors, as it can harm and degrade the environment. It is worth noting the studies related to environmental behavior by Bratt (1999); CorralVerdugo and Pinheiro (1999); Schmuck and Schultz (2002); and Gonçalves-Dias, Teodósio, Carvalho and Silva (2009), who conceptualize sustainable behavior as actions that are directed, effective, and deliberate and that focus on environmental protection, requiring both social and individual aspects.

According to Gonçalves-Dias et al. (2009), sustainable behavior occurs through five dimensions: conscious consumption, concern with garbage, boycott via consumption, mobilization, and the domestic environment. In the dimension of engaged consumption, variables referring to individual attitudes regarding consumption are considered, expressing the level of awareness about environmental issues that involve the posture of the manufacturers and have a more active character in the search for ecologically correct product options. The concern with garbage, meanwhile, includes variables related to the attitude of the individuals regarding garbage and the cleaning of domestic and public environments.

Boycott via consumption brings together behavioral variables related to consumption, but the character of the individual posture indicates a greater propensity to penalize ecologically incorrect products and services. Regarding mobilization, the behavioral variables observed are related to a proactive stance in the search for awareness of other individuals regarding environmental issues. The domestic environment dimension includes variables related to the individual's behavior at home including the daily use of natural resources such as energy and water (Gonçalves-Dias et al., 2009).

In this study, we present sustainable behavior from the point of view of individual concern with environmental issues, which, consequently, are directly related to social issues (Gonçalves-Dias et al., 2009; Kuckertz \& Wagner, 2010; Pato \& Tamayo, 2006). Sustainable behavior refers to the development of alternatives that seek to reduce environmental degradation with a focus, above all, on protection for the development of social and environmental solutions.

\subsection{Innovative Behavior}

Schumpeter (2017) highlights innovation as a determining factor for entrepreneurship, due to the new combinations that stimulate competitiveness and economic development. Carland, Hoy, Boulton, and Carland (2007) emphasize that entrepreneurship has psychological and social aspects related to the potential of the individual. A person with an innovative profile is therefore more likely to be motivated and have knowledge, skills, and attitudes related to innovation (Schumpeter, 2017).

Innovative behavior is represented by the accumulation of knowledge, experiences, and individual skills (Marcati, Guido, \& Peluso, 2008), as well as the implementation of ideas and procedures or working groups (Yusof, Imm, Ann, \& Rahman, 2018). In addressing innovative behavior from the perspective of cognitive styles, we highlight the Kirton Adaptation-Innovation (KAI) theory, developed by Kirton (1976), which examines and characterizes differences in how individuals can solve problems by considering cognitive style, based on the assumption that people are creative and original in the decisionmaking process (Stum, 2009).

The way in which each individual solves problems is different, however, and this makes the KAI theory a bipolar construct, formed by a continuum with two opposing poles: the adapter end and the innovative edge, which helps to define the best approach for each individual in problem solving (Hutchinson \& Skinner, 2007). The individual with an adaptive cognitive style solves problems by relying on existing paradigms because he or she is attentive to details and proceeds according to organizational theories, policies, and practices (Kirton, 1984). The individual with an

Revista de Negócios, v. 24, n. 3, p. 7-26, July, 2019. 
innovative cognitive style uses change to reconstruct the problem, breaking the patterns of thought and action, to provide unexpected solutions, because he or she seeks to do things differently and has the following characteristics: preference for dynamism and creativity, originality, preference for change, and efficiency for details (Foxall \& Hackett, 1992; Kirton, 1984).

In the conception of Kickul, Gundry, Barbosa, and Whitcanack (2009), cognitive style can contribute to the development of entrepreneurial self-efficacy, as the individual considers the possibility of becoming an entrepreneur, because he or she conjectures the different abilities necessary to create an enterprise, and their cognitive styles can foster some selfperceptions and inhibit others by refining the different types of self-efficacy. The innovative cognitive style also positively influences creativity and the introduction of new opportunities (Mirjana, Ana, \& Marjana, 2018). Innovation is considered a characteristic of entrepreneurs, who recognize opportunities and provide creative and innovative solutions (Armstrong \& Hird, 2009).

Research involving the relationship between cognition and EI is still incipient (Mirjana et al., 2018), although cognitive styles have been investigated as antecedents of entrepreneurial behavior by scholars such as Barbosa, Gerhardt and Kickul (2007); Kuckertz and Wagner (2010); Molaei, Reza Zali, Mobaraki and Farsi (2014); and Camozzato, Serafim, Gentleman, Lizote and Verdinelli (2018). Ahmed et al. (2010) investigated the impact of personal characteristics, demographics, and entrepreneurial education on EI among university students in Pakistan. The results indicated the influence of innovation, family context, and previous entrepreneurial experience on EI. Camozzato et al. (2018) analyzed the relationship between cognitive styles and EI among Brazilian Management students from the perspective of KAI theory and the theory of planned behavior, showing that an innovative cognitive style, personal attitude, and control of perceived behavior are positively related to EI, while subjective norms were negatively related.

Higher education institutions (HEIs) are favorable environments that stimulate the latent eagerness to undertake, just as an innovative cognitive style provides the self-perception for the development of skills to create new business (Camozzato et al., 2018; Foxall \& Hackett, 1992;
Kickul, Gundry, Barbosa, \& Whitcancak, 2009). Empirical studies considering the relationship between such constructs could contribute to the definition and implementation of actions that might impact Brazilian higher education and encourage the formation of entrepreneurs prepared to deal with uncertainties and challenges in the labor market.

In view of the above, the KAI theory is used under the theoretical lens of Kirton (1976) and Foxall and Hackett (1992) to align innovative behavior with the EI of university students. A review of the literature on EI is presented below.

\subsection{Entrepreneurial Intention}

Shapero and Sokol (1982) and Shapero (1985) mark the starting point of the empirical and conceptual literature on EI. These studies provide the theoretical and methodological bases for the development of other investigations about EI. With the evolution of the literature on the subject, some theories have been considered crucial to explain EI (Autio, Keeley, Klosten, Parker, \& Hay 2001; Liñán \& Fayolle, 2015), as entrepreneurial activity is thought of as a behavior intentionally planned (Birchler \& Teixeira, 2017; Krueger, Reily, \& Carsrud, 2000; Zhang, Wang, \& Owen, 2015).

EI refers to the effort expended by the individual to carry out entrepreneurial activity (Cantner, Goethner, \& Silbereisen, 2017; Paul, Hermel, \& Srivatava, 2017) as a predisposition to create or expand a business and it can also be influenced by many factors, such as time, family context, gender, innovation, financial resources and competence (Khuong \& An, 2016; Paiva et al., 2018; Teixeira \& Davey, 2010). EI is an antecedent of behavior, so it is pertinent to emphasize that the stronger the intention, the greater the probability the behavior will be realized (Ajzen, 1991; Liñán \& Chen, 2009).

The model of Shapero and Sokol (1982) is formed by three behavioral constructs that precede the EI: perception of desirability, based on the desire of the individual to open a certain business; propensity to act, which refers to the force that drives the individual's action to start a new business; and perception of viability, which refers to the level of belief that the individual has in starting a new business, through the interpretation of behaviors for the possible desired results that will be generated by the business. These constructs

Revista de Negócios, v. 24, n. 3, p. 7-26, July, 2019. 
highlight individual intention, which is characterized as a predictor of behavior.

In the conception of Krueger, Reilly, and Carsrud (2000) and Esfandiar et al. (2019), the EI models provide a coherent, generalizable, and robust theoretical framework for understanding the process of predicting entrepreneurial activities, because situational or individual variables are often considered inefficient predictors of EI. The theoretical model of EI most used is the theory of planned behavior (TPB), developed by Ajzen (1991), and elaborated by, for example, Fayolle and Liñán (2014), Martins, Santos, and Silveira (2018) and Esfandiar et al. (2019). The TPB postulates that intention explains behavior before a certain situation and provides evidence of the relationship of attitudes in the behaviors (Ajzen, 1991).

Carvalho and González (2006) elucidate external and individual factors that influence the behavioral attitude-intention and that are denoted in studies referring to entrepreneurship and especially to EI. Complementing this idea, Bergmann, Hundt, and Sternberg (2016) highlight the contextual perspective, more specifically the university context, which can directly contribute to the awakening the entrepreneurial spirit in the student. Before the alignment between sustainable behavior, the innovator and the EI, the hypotheses of the research are presented, which are basis for the analysis and discussion of the results of this investigation.

\subsection{Development of Hypotheses}

Studies using different theoretical and methodological approaches on entrepreneurship have been carried out with university students, seeking to investigate the factors (individual, social, and professional) that influence their EIs (Zampetakis \& Moustakis, 2006), to understand the factors that affect EI, as well as which are affected by it.

There is a gap in entrepreneurial participation between men and women that has been attracting academic attention (Arshad, Farooq, Sultana, \& Farooq, 2016; Hughes, Jennings, Brush, Carter, \& Welter, 2012). The choice of occupation may depend on gender, and the proportion of the adult female population involved in entrepreneurial activity is smaller than the male, which suggests that the difference between the genders can influence the development of EI (Arshad et al., 2016; Hindle, Klyver, \& Jennings, 2009).

The difference between male and female involvement in entrepreneurial activities can be explained through individual cognition, as well as environmental influence (Santos, Roomi, \& Liñán, 2016). In relation to individual cognition, men and women have different perceptions of reality, and women, in particular, are less likely to perceive business opportunities and more likely to identify financial barriers than men (Bruin, Brush, \& Welter, 2007). In terms of environmental context, the cultural values and beliefs of a given country can provide a favorable socio-economic context for entrepreneurship (Mueller \& Thomas, 2001).

Empirical research indicates that women are less prone to entrepreneurship than men (Arshad et al., 2016; Cañizares \& Garcia, 2010; Rico \& Cabrer-Borrás, 2018; Santos et al., 2016), who are more likely to be involved in entrepreneurship (Delmar \& Davidsson, 2000), which is perceived as a prescriptive male domain (Winn, 2005). While men are more independent, assertive, and selfreliant, women pay more attention to the opinions of their social referents, especially when they want to make decisions about their careers (Sidanius \& Pratto, 2001). With this in mind, it seems likely that EI may be different for each gender, and this gave rise to the following hypothesis, $\mathrm{H}_{1}$ : Gender positively influences the EI of students in the Administration and Executive Secretariat courses.

Individual social and environmental factors, such as personal and family background, may also influence EI (Gürol \& Atsan, 2006; Mueller \& Dato-on, 2008; Schröder \& Schmitt-Rodermund, 2006; Van Auken, Stephens, Fry, \& Silva, 2006; Wang \& Wong, 2004; Zampetakis \& Moustakis, 2006). The results of empirical studied by Teixeira and Davey (2010), Arregle et al. (2015), Randerson, Bettinelli, Fayolle and Anderson (2015), Sieger and Minola (2017) and Paiva et al. (2018) have elucidated that family context can influence the EI, as well as the development of enterprises.

EI is influenced by family history, as individuals who descend from entrepreneurial parents tend to develop EI and/or entrepreneurial behavior (Rodermund, 2004; Zampetakis \& Moustakis, 2006) due to the context in which they are inserted. They are also more likely to develop entrepreneurial skills, because parental behavior can support self-confidence, autonomy, leadership,

Revista de Negócios, v. 24, n. 3, p. 7-26, July, 2019. 
and control (Rodermund, 2004). This suggests the second hypothesis, $\mathrm{H}_{2}$ : Entrepreneurial relatives positively influence the EI of students in the Administration and Executive Secretariat courses.

The association between entrepreneurship and environmental sustainability is explained by the individual's intention, constituting itself as a support for entrepreneurial decisions (Font, Garay, \& Jones, 2016; Muñoz \& Cohen, 2018; Shane, Locke, \& Collins, 2003). Recognition of entrepreneurship as a solution to reduce environmental degradation and social inequality has prompted the field to identify a new type of entrepreneurial activity (Muñoz \& Cohen, 2018), which - in line with sustainable behavior (focusing on the environment) (Kuckertz \& Wagner, 2010) can create a sustainable society that requires systemic transformations, relating environmental and commercial factors (Muñoz, 2018).

The potential opportunity to create value from an environmental perspective by introducing and advocating for the adoption of ecologically sound ideas, products, and processes, as well as the use of new technologies for collective profits, can mitigate environmental impacts to the benefit of society (Schlange, 2009). The entrepreneur therefore becomes an agent of economic, social, and environmental change, because, by recognizing opportunities, he or she can stimulate economic development and solve environmental and social problems through the creation of his or her business (Boszczowski \& Teixeira, 2012; Fischer et al., 2018). This leads to $\mathrm{H}_{3}$ : Sustainable behavior exerts a positive influence on the EI of the students in the Administration and Executive Secretariat courses.

Soomro and Shah (2015) emphasize that EI depends on attitudes toward entrepreneurship, such as the pursuit of achievement, self-esteem, personal control, and innovation. The academic experience of entrepreneurs foresees significant attributes and motivation to achieve, and it is up to universities to provide means to stimulate students' creativity and innovation so that they take responsibility for their actions and develop EI (Ali, Topping, \& Tariq, 2010).

Research by Marcati, Guido, and Peluso (2008); Ahmed et al. (2010); Wurthmann (2014); Soomro and Shah (2015); and Kollmann, Stöckmann, Meves, and Kensbock (2017) has noted that entrepreneurial individuals tend to be creative and original with innovative behavior in making decisions and solving problems; this makes it possible to highlight $\mathrm{H}_{4}$ : Innovative behavior has a positive influence on the EI of students in the Administration and Executive Secretariat courses.

In light of the hypotheses that have emerged based on the empirical and conceptual literature on entrepreneurship, innovation, and sustainability, a synthesis of the hypothetical model of the study is presented to show the focus of analysis in the results of the present research, based on university students in the Administration and Executive Secretariat courses.

Table 1. Synthesis of hypotheses

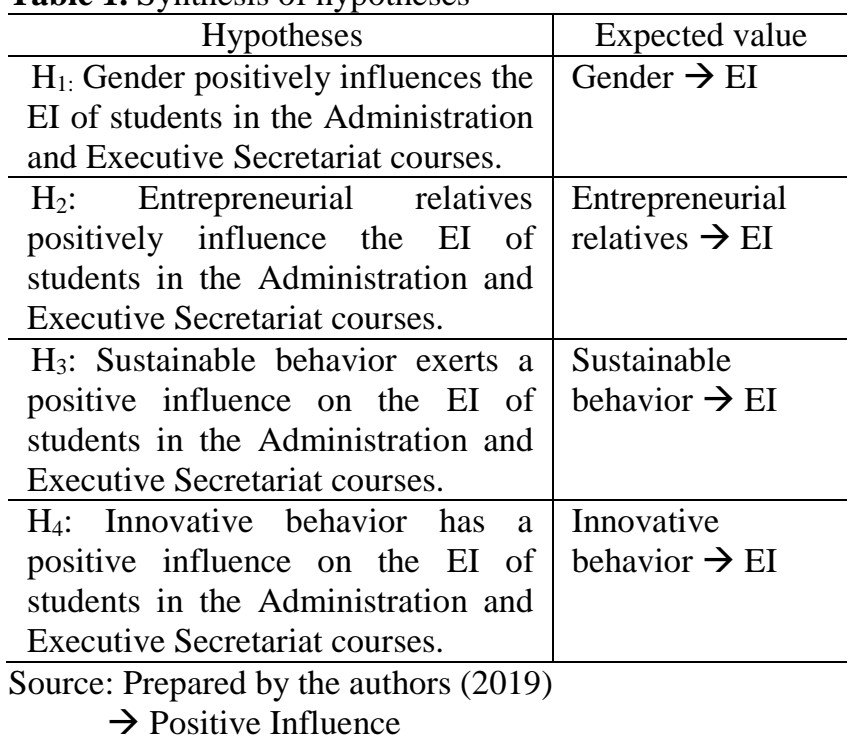

Following the approaches that led to the development of the research hypotheses, the methodological procedures for this study are outlined below, taking into account the influence of sustainable and innovative behavioral constructs on the EI of university students in the Administration and Executive Secretariat courses.

\section{Methodology}

This research was descriptive and of a quantitative nature from the perspective of Collis and Hussey (2005). Surveys were used to obtain the primary data (Hair, Black, Babin, Anderson, \& Tatham, 2009) from university students in courses related to management, such as the Administration and Executive Secretariat courses, since Paço et al. (2011) and Barbosa and Durante (2013) have emphasized the studies and practices related to entrepreneurship in these courses, thus justifying the universe investigated.

Thomas and Mueller (2000) have also 
highlighted reasons for choosing university students in research related to entrepreneurship, and this further intensifies the justification of this universe for the study: (a) the difficulty of accessibility for entrepreneurs that already have their business; and (b) the relevance of identifying EI among university students.

Following a non-probabilistic approach, based on the availability and convenience of the researchers (Cooper \& Schindler, 2011), we selected a sample of 285 undergraduates from the Administration course and 144 from the Executive Secretariat course, totaling 429 students from a public university located in a State of Northeast Brazil that is considered the best university in the region among public and private institutions according to the national ranking released in 2017 by the Ministry of Education. The sample size had as a criterion a minimum number of five times more observations than the number of variables investigated (Hair et al., 2009).

Students with EI may generate more employability in the future, enhancing local and regional development, as highlighted by Pereira, Cordeiro, Silva, and Batista (2013), and may be more likely to have an impact on the economy, society, and the environment (Paiva et al., 2018), which reinforces the justification for choosing university students for the scope investigated.

The research instrument was structured using a set of items, made up of a 5-point Likert-type scale. For entrepreneurial intent, a "yes/no" dichotomous analysis was adopted (Liñán \& Chen, 2009), while for sustainable behavior, the scale ranged from 1 "never" to 5 "always" (GonçalvesDias et al., 2009); and for innovative behavior, from "totally disagree" to "totally agree" (Foxall \& Hackett, 1992).

After structuring the complete version of the data collection instrument, a pre-test was carried out with 60 students from the Management course of an HEI in March 2018, to verify the understanding of the respondents and provide evidence possible inconsistencies. Data collection occurred in April and May 2018, with the application of the questionnaire in the classroom by the researchers, who provided instructions on how to respond. The scale items that compose the questionnaire are shown in Table 2.

Table 2. Model Variables

\begin{tabular}{c|c|c} 
Constructs & Item & Question \\
\hline
\end{tabular}

\begin{tabular}{|c|c|c|}
\hline \multirow{16}{*}{$\begin{array}{l}\text { Sustainable } \\
\text { Behavior }\end{array}$} & SB1 & $\begin{array}{l}\text { I have paid more for } \\
\text { environmentally correct products. }\end{array}$ \\
\hline & SB2 & $\begin{array}{l}\text { I try to buy products made from } \\
\text { recycled material. }\end{array}$ \\
\hline & SB3 & $\begin{array}{l}\text { I have convinced others not to buy } \\
\text { products that harm the environment. }\end{array}$ \\
\hline & SB4 & $\begin{array}{l}\text { Concerns about the environment } \\
\text { affect my purchase decision. }\end{array}$ \\
\hline & SB5 & $\begin{array}{l}\text { I read the label carefully before } \\
\text { deciding to purchase. }\end{array}$ \\
\hline & SB6 & $\begin{array}{l}\text { When there is no bin near, I keep the } \\
\text { paper I no longer want in my pocket. }\end{array}$ \\
\hline & SB7 & I avoid throwing paper on the floor. \\
\hline & SB8 & I help keep the streets clean. \\
\hline & SB9 & $\begin{array}{l}\text { I buy products from a company even } \\
\text { though I know that it pollutes the } \\
\text { environment. }\end{array}$ \\
\hline & SB10 & $\begin{array}{l}\text { I avoid using products manufactured } \\
\text { by a company that pollutes the } \\
\text { environment. }\end{array}$ \\
\hline & SB11 & $\begin{array}{l}\text { I talk about the importance of the } \\
\text { environment with other people. }\end{array}$ \\
\hline & SB12 & $\begin{array}{l}\text { I mobilize people for the } \\
\text { conservation of public spaces. }\end{array}$ \\
\hline & SB13 & $\begin{array}{l}\text { I try to reduce my consumption of } \\
\text { scarce natural resources. }\end{array}$ \\
\hline & SB14 & I take long showers. \\
\hline & SB15 & $\begin{array}{l}\text { I keep the refrigerator open for a } \\
\text { long time, looking at what's inside. }\end{array}$ \\
\hline & SB16 & $\begin{array}{l}\text { When I'm at home, I leave the lights } \\
\text { on in unused environments. }\end{array}$ \\
\hline \multirow{13}{*}{$\begin{array}{l}\text { Innovative } \\
\text { Behavior }\end{array}$} & IB1 & $\begin{array}{l}\text { I think of solutions to seemingly } \\
\text { dead-end situations. }\end{array}$ \\
\hline & IB2 & I'd rather create than improve. \\
\hline & IB3 & $\begin{array}{l}\text { I have new perspectives for old } \\
\text { problems. }\end{array}$ \\
\hline & IB4 & $\begin{array}{l}\text { I can hold a position of disagreement } \\
\text { within a group. }\end{array}$ \\
\hline & IB5 & I'm a stimulating person. \\
\hline & IB6 & I have original ideas. \\
\hline & IB7 & I share my ideas. \\
\hline & IB8 & $\begin{array}{l}\text { I like to vary already established } \\
\text { routines. }\end{array}$ \\
\hline & IB9 & $\begin{array}{l}\text { I prefer gradual rather than radical } \\
\text { change. }\end{array}$ \\
\hline & IB10 & $\begin{array}{l}\text { I deal with several new ideas at the } \\
\text { same time. }\end{array}$ \\
\hline & IB11 & $\begin{array}{l}\text { I prefer gradual rather than radical } \\
\text { change. }\end{array}$ \\
\hline & IB12 & I often risk doing things differently. \\
\hline & IB13 & $\begin{array}{l}\text { I need the stimulus of frequent } \\
\text { change. }\end{array}$ \\
\hline
\end{tabular}

Source: Prepared by the authors (2019).

In addition to these constructs, the gender and family entrepreneurs were measured through the experience of the parents to verify whether the university students have entrepreneurial parents, parents who were once entrepreneurs, but no are, or parents who have never been enterprising.

Revista de Negócios, v. 24, n. 3, p. 7-26, July, 2019. 
Exploratory factor analysis (EFA) was used to reduce the number of variables and to group them in their respective constructs, with Varimax orthogonal rotation type, which is often used to reduce the number of variables. The criterion of the substitute variable for each construct was adopted, using the variable with the highest factor loading because it is the one with the greatest explanatory power in the construct (Hair et al., 2009). Afterwards, logistic regression was carried out to analyze the influence of the independent variables (sustainable behavior, innovative behavior, gender, and entrepreneurial family) on the dependent variable (EI). Statistical analyses were processed using the Statistical Package for the Social Sciences (SPSS) software (version 23.0).

\section{Analysis}

\subsection{Sample Profile}

In the investigated sample, there were 159 male students $(37.1 \%)$ and 270 female students (62.9\%), with women predominating in both courses. Of the 429 university students, 228 had EI (53.1\%), 171 did not have EI (39.9\%), and 30 were entrepreneurs (7\%). In both courses, students with EI predominated $53.3 \%$ and $52.6 \%$ with EI in the Administration and Executive Secretariat course, respectively). The average age was 23 years, varying between 16 and 56 years, the majority were single and in the first semester of both courses.

Regarding family background and university student EI in the Administration Course, there was a certain parental influence, as 152 had entrepreneurial parents, and of these, 70 had EI (68\%), 23 did not $(22.3 \%)$, and 10 were entrepreneurs (9.7\%). Among the 114 students without entrepreneurial parents, 45 had EI (41.7\%), $57 \mathrm{did}$ not $(52.8 \%)$, and 6 were entrepreneurs (5.6\%; see Table 3$)$.

Table 3. Association between EI and family entrepreneurs (Administration course)

\begin{tabular}{lcccc}
\hline \multirow{1}{*}{$\begin{array}{l}\text { Parent } \\
\text { Experience }\end{array}$} & Yes & No & Entrepreneur & Total \\
\cline { 2 - 4 } & 70 & 23 & 10 & 103 \\
\hline $\begin{array}{l}\text { Yes, at least one } \\
\text { is an }\end{array}$ & $68 \%$ & $22.3 \%$ & $9.7 \%$ & $100 \%$ \\
$\begin{array}{l}\text { entrepreneur } \\
\text { No, but at least }\end{array}$ & 37 & 34 & 3 & 74 \\
$\begin{array}{l}\text { one parent has } \\
\text { been an }\end{array}$ & $50 \%$ & $45.9 \%$ & $4.1 \%$ & $100 \%$ \\
entrepreneur & & & & \\
\hline
\end{tabular}

\begin{tabular}{lcccc}
\hline No parent was & 45 & 57 & 6 & 108 \\
ever an & $41.7 \%$ & $52.8 \%$ & $5.6 \%$ & $100 \%$ \\
entrepreneur & & & & \\
Total & 152 & 114 & 19 & 285 \\
& $53.3 \%$ & $40 \%$ & $6.7 \%$ & $100 \%$ \\
\hline
\end{tabular}

Source: Research data (2019).

Concerning the experience of entrepreneurial parents and the EI of university students in the Executive Secretariat Course, here, too, there appeared to be a family influence on EI, as 52 had entrepreneurial parents, and of these, 29 had EI (55.8\%), 15 did not (28.8\%), and 8 were entrepreneurs (15.4\%). Of the 52 students who did not have entrepreneurial parents, $50 \%$ did not have EI, making it possible to infer the influence of entrepreneurial relatives on EI, as can be seen in Table 4.

Table 4. Association between EI and family entrepreneurs (Executive Secretariat course)

\begin{tabular}{|c|c|c|c|c|}
\hline \multirow[b]{2}{*}{$\begin{array}{c}\text { Parent } \\
\text { Experience }\end{array}$} & \multicolumn{3}{|c|}{ Entrepreneurial Intention } & \multirow{2}{*}{ Total } \\
\hline & Yes & No & Entrepreneur & \\
\hline Yes, at least one & 29 & 15 & 8 & 52 \\
\hline $\begin{array}{l}\text { parent is an } \\
\text { entrepreneur }\end{array}$ & $55.8 \%$ & $28.8 \%$ & $15.4 \%$ & $100 \%$ \\
\hline No, but at least & 23 & 16 & 1 & 40 \\
\hline $\begin{array}{l}\text { one parent has } \\
\text { been an } \\
\text { entrepreneur }\end{array}$ & $57.5 \%$ & $40 \%$ & $2.5 \%$ & $100 \%$ \\
\hline No parent was & 24 & 26 & 2 & 52 \\
\hline $\begin{array}{l}\text { ever an } \\
\text { entrepreneur }\end{array}$ & $46.2 \%$ & $50 \%$ & $3.8 \%$ & $100 \%$ \\
\hline Total & $\begin{array}{c}76 \\
52.8 \%\end{array}$ & $\begin{array}{c}57 \\
39.6 \%\end{array}$ & $\begin{array}{c}11 \\
7.6 \%\end{array}$ & $\begin{array}{c}144 \\
100 \%\end{array}$ \\
\hline
\end{tabular}

Source: Research data (2019).

In view of these analyses, it is noteworthy that both courses show a statistically significant association between EI and an entrepreneurial family, which is indicated by the significance of the chi-square test, with $\mathrm{p}$ values lower than 0.05 . There is, therefore, evidence to infer that entrepreneurial family members do have an influence on EI, which denotes the non-rejection of $\mathrm{H}_{2}$ : Entrepreneurial family members positively influence the EI of students in the Administration and Executive Secretariat courses; this supports the findings of Ching and Kitahara (2015); Loiola, Gondim, Pereira and Ferreira (2016); Paiva, Bandeira and Soares (2016); and Paiva et al. (2018), with the latter research also carried out with Brazilian university students.

4.2 Factorial Analysis for Sustainable and 
Innovative Behavioral Constructs

The factorial analysis for sustainable behavior was based on the theoreticalmethodological perspective of Gonçalves-Dias et al. (2009). This factorial analysis revealed $73.84 \%$ of variance explained, with the results of the Kaiser-Meyer-Olkin value $(\mathrm{KMO}=0.761)$ and Bartlett sphericity test (chi-square $=1188.837$ and $\mathrm{p}=0.000$ ) indicating that the analysis is significant and explained by the adopted variables (Table 5).

Table 5. Factor analysis for sustainable behavior

\begin{tabular}{|c|c|c|c|c|c|}
\hline & \multicolumn{5}{|c|}{ Factor Loadings } \\
\hline & $\begin{array}{l}\text { Conscious } \\
\text { consumption }\end{array}$ & $\begin{array}{c}\text { Concern } \\
\text { with } \\
\text { garbage }\end{array}$ & Mobilization & $\begin{array}{l}\text { Domestic } \\
\text { environm } \\
\text { ent }\end{array}$ & $\begin{array}{l}\text { Boycott } \\
\text { via } \\
\text { consump } \\
\text { tion }\end{array}$ \\
\hline SB1 & .808 & & & & \\
\hline SB2 & .778 & & & & \\
\hline SB3 & .740 & & & & \\
\hline SB4 & .823 & & & & \\
\hline SB6 & & .830 & & & \\
\hline SB7 & & .898 & & & \\
\hline SB8 & & .750 & & & \\
\hline SB15 & & & .876 & & \\
\hline SB16 & & & .723 & & \\
\hline SB12 & & & & .924 & \\
\hline SB9 & & & & & .962 \\
\hline
\end{tabular}

Source: Research data (2019).

With the substitute variable criteria for each construct of sustainable behavior, five constructs with their most representative variables are shown: conscious consumption, SB4: "Concerns about the environment interfere with my purchase decision" (factor loading of 0.823); concern with garbage, SB7: "I avoid throwing paper on the floor" (factor loading of 0.898); domestic environment, SB15: "Long shower" (factor loading of 0.876); mobilization, SB12: "I mobilize people for the conservation of public spaces" (factor loading of 0.924); and boycott via consumption, SB9: "I buy products from a company even though I know that it pollutes the environment" (factor loading of 0.962).

For innovative behavior, the perspective of Foxall and Hackett (1992) is used, based on the KAI theory (Kirton, 1976), which explained $68.20 \%$ of variance, with the results of the KMO value $(\mathrm{KMO}=0.639)$ and the Bartlett sphericity test (chi-square $=333.677$ and significance of 0.000 ), emphasizing that the factorial analysis is also significant for innovative behavior (Table 6).
Table 6. Factor analysis for innovative behavior

\begin{tabular}{ccccc}
\hline & \multicolumn{4}{c}{ Factor Loadings } \\
\cline { 2 - 5 } & $\begin{array}{c}\text { Preference for } \\
\text { dynamism and } \\
\text { creativity }\end{array}$ & $\begin{array}{c}\text { Appropriateness } \\
\text { to originality }\end{array}$ & $\begin{array}{c}\text { Efficiency } \\
\text { in details }\end{array}$ & $\begin{array}{c}\text { Preference } \\
\text { for change }\end{array}$ \\
\hline IB5 & .715 & & & \\
IB6 & .745 & & & \\
IB7 & .766 & & & \\
IB1 & & .821 & $\mathbf{8 2 5}$ & \\
IB3 & & .781 & .789 & \\
IB9 & & & & $\mathbf{. 9 5 7}$ \\
IB11 & & & & \\
IB13 & & & & \\
\hline
\end{tabular}

Source: Research data (2019)

Variables with higher factor loadings included: Preference for dynamism and creativity, IB7: "I share my ideas" (factor loading of 0.766); appropriateness to originality, IB1: "I think of solutions for situations that seem to have no way out" (factor loading of 0.821); efficiency in details, IB9: "I prefer gradual rather than radical change" (factor loading of 0.825); and preference for change, IB13: "I need the stimulus of frequent change" (factor loading of 0.957) representing the innovative behavior constructs in this study.

\subsection{Results of Regression Models}

In view of the structures of the factorial analysis, nine behavioral constructs are considered through their respective substitution variables (the most representative ones). Thus, two regression models were used, one for each course (Administration and Executive Secretariat) with the dependent variable (EI) to analyze the influence of sustainable and innovative behavioral constructs on the EI of university students. The influence of gender and family entrepreneurship on the EI of these university students is also verified.

Individual who are entrepreneurs are incorporated into EI to have a dichotomous "yes" or "no" variable for the purposes and analysis of the regression data, which is justified by Ajzen (1991) who elucidates that the greater the individual's intention, the stronger and more likely the manifestation of the behavior.

For the first analysis of students in the Administration course, we highlight the sample of 285 individuals for the logistic regression model, which has an efficiency of $74.7 \%$ to explain EI, since the Cox and Snell pseudo-coefficient was 0.259 and Nagelkerke's was 0.350 . The results of

Revista de Negócios, v. 24, n. 3, p. 7-26, July, 2019. 
the Hosmer and Lemeshow test, with the statistic value of 14.830 and $p=0.063$, suggest the good predictive capacity of the model (Table 7).

Table 7. Logistic regression analysis (Administration course)

\begin{tabular}{lccc}
\hline Variables & B & Sig. & Exp(B) \\
\hline Conscious consumption & -.116 & .501 & .890 \\
Concern with garbage & -.678 & $\mathbf{. 0 6 2}$ & $\mathbf{. 5 0 8}$ \\
Boycott via consumption & .048 & .782 & 1.049 \\
Mobilization & .336 & $\mathbf{. 0 0 5}$ & $\mathbf{1 . 3 9 9}$ \\
Domestic environment & .234 & .173 & 1.264 \\
Preference for dynamism and & -.132 & .437 & .876 \\
creativity & -.031 & .830 & .969 \\
Efficiency in details & $\mathbf{. 8 4 1}$ & $\mathbf{. 0 0 0}$ & $\mathbf{2 . 3 1 9}$ \\
Appropriateness to originality & $\mathbf{. 4 6 0}$ & $\mathbf{. 0 0 4}$ & $\mathbf{1 . 5 8 5}$ \\
Preference for change & $\mathbf{. 5 4 5}$ & $\mathbf{. 0 6 4}$ & $\mathbf{1 . 7 2 5}$ \\
Gender (Male) & $\mathbf{1 . 4 0 8}$ & $\mathbf{. 0 0 0}$ & $\mathbf{4 . 0 8 9}$ \\
Parent experience (at least one & & & \\
is an entrepreneur) & .503 & .158 & 1.654 \\
Parent experience (at least one & & & \\
was already an entrepreneur) & -1.889 & .390 & .151 \\
Constant & & &
\end{tabular}

Source: Research data (2019).

Concerning sustainable behavior among university students in the Administration course, concern with garbage negatively influences $\mathrm{EI}$ ( $\mathrm{p}=$ $0.062 ; \mathrm{B}=-0.678 ; \operatorname{Exp}[\mathrm{B}]=0.508)$, which shows that individuals who do not avoid throwing paper on the floor were more likely to have EI compared to those who avoid this behavior. Concern with garbage is therefore not a factor that has a positive influence on the EI of university students. The influence of mobilization on EI $(\mathrm{p}=0.005 ; \mathrm{B}=$ $0.336 ; \operatorname{Exp}[\mathrm{B}]=1.399)$ is verified, however, which explains that people who are more concerned about mobilizing others on the importance of conservation of public spaces and the environment are approximately $40 \%$ more likely to demonstrate EI compared to people without this concern; this coincides with the findings of Kuckertz and Wagner (2010).

Based on the innovative behavior of these students, appropriateness to originality $(p=0.001$; $\mathrm{B}=0.657)$ and preference for change $(\mathrm{p}=0.007 ; \mathrm{B}$ $=0.434$ ) are also influential on EI. It is evident that the most original university students (with new perspectives on the problems) are twice as likely to have EI (Exp $[B]=2.319)$; and those who prefer constant changes have a $58.5 \%$ chance of having EI $(\operatorname{Exp}[\mathrm{B}]=1.585)$. Silva, Gomes, and Correia (2009) recognize innovative behavior as a volitional manifestation of the entrepreneur in presenting innovative processes, products, or services through creativity or experimentation, which reinforces the arguments of Marcati et al. (2008); Ahmed et al. (2010); Wurthmann (2014); Soomro and Shah (2015); and Subotic, Maric, Mitrovic, and Mesko (2018).

The influence of family entrepreneurs on college students' $\mathrm{EI}$ is considered with the variable parental experience (at least one is entrepreneur; $\mathrm{p}$ $=0.000 ; \mathrm{B}=1.408 ; \operatorname{Exp}[\mathrm{B}]=4.089)$; students with entrepreneurial parents are four times more likely to have EI than those who do not have entrepreneurial parents. This suggests the strong influence of the family context on the formation of EI, which coincides with Randerson et al. (2015); Zampetakis, Bakatsaki, Litos, Kafetsios, and Moustakis (2017); and Wang, Wang and Chen (2018). Men are $72.5 \%$ more likely to have EI than women $(\mathrm{p}=0.064 ; \mathrm{B}=0.545 ; \operatorname{Exp}[\mathrm{B}]=1.725)$, which corroborates the findings of Brenner (1982), De Wit and Van Winden (1989), Carvalho and González (2006), Lewis (2006), and Hallam, Zanella, Dosamantes, and Cardenas (2016).

The other logistic regression model refers to the 144 students in the Executive Secretariat course. This model has an efficiency of $69 \%$ to explain the EI, with the value of the Cox and Snell pseudo-coefficient being 0.171 and Nagelkerke's $=$ 0.231 . The Hosmer and Lemeshow test makes it possible to conclude the good predictive capacity of the model, with the statistic value of 5.674 and $p$ $=0.684$ (Table 8$)$.

Table 8. Logistic regression analysis (Executive Secretariat course)

\begin{tabular}{lccc}
\hline Variables & B & Sig. & Exp(B) \\
\hline Conscious consumption & -.071 & .756 & .931 \\
Concern with garbage & .252 & .629 & 1.286 \\
Boycott via consumption &.- .452 & $\mathbf{. 0 4 9}$ & $\mathbf{. 6 3 7}$ \\
Mobilization & .196 & .305 & 1.217 \\
Domestic environment & .204 & .406 & 1.226 \\
Preference for dynamism and & .382 & .127 & 1.465 \\
creativity & & & \\
Efficiency in details & -.018 & .934 & .982 \\
Appropriateness to originality & -.128 & .663 & .880 \\
Preference for change & $\mathbf{. 4 0 4}$ & $\mathbf{. 0 5 0}$ & $\mathbf{1 . 4 9 8}$ \\
Gender (Male) & .051 & .919 & 1.052 \\
Parent experience (at least one & $\mathbf{. 9 5 1}$ & $\mathbf{. 0 5 2}$ & $\mathbf{2 . 5 8 7}$ \\
is an entrepreneur) & & & \\
Parent experience (at least one & .457 & .365 & 1.580 \\
was already an entrepreneur) & & & \\
Constant & .932 & .298 & 2.538 \\
\hline Source: Research data (2019). & & &
\end{tabular}

Source: Research data (2019).

Regarding sustainable behavior among students in the Executive Secretariat course, there appears to be a negative influence of the boycott

Revista de Negócios, v. 24, n. 3, p. 7-26, July, 2019. 
via consumption factor on $\mathrm{EI}(\mathrm{p}=0.049 ; \mathrm{B}=$ $-0.452 ; \operatorname{Exp}[\mathrm{B}]=0.637$ ), showing that individuals who buy products from a company, even knowing that it pollutes the environment, are less likely to have EI than individuals who avoid such behavior, which makes it possible to infer that respondents are motivated to boycott via consumption by ideologies and neglect companies that pollute the environment, perhaps because executive secretariat students consider it relevant that companies change their actions in relation to the environment (Cruz \& Botelho, 2016).

Concerning the innovative behavior of students in the Executive Secretariat course, it is important to highlight that preference for change has a positive influence on $\mathrm{EI}(\mathrm{p}=0.050, \mathrm{~B}=0.404$ and $\operatorname{Exp}(\mathrm{B})$ of 1.498), which suggests that students who need the stimulus of constant change are approximately $50 \%$ more likely to have EI than those who do not prefer this constant change, which coincides with the results of Marcati et al. (2008), Ahmed et al. (2010), Wurthmann (2014), Soomro and Shah (2015), and Paiva et al. (2018).

The influence of family entrepreneurs on the EI of students is also shown, with the parental experience variable (at least one is entrepreneur; $p$ $=0.052 ; \mathrm{B}=0.951 ; \operatorname{Exp}[\mathrm{B}]=2.587$ ) indicating that individuals with entrepreneurial parents are twice as likely to have EI as those who do not have entrepreneurial parents. This is in line with prior research by Teixeira and Davey (2010), Fayolle and Gailly (2015), Sieger and Minola (2017), and Paiva et al. (2018), for example.

In view of the results of the two regression models, it appears that gender (male) only had a positive influence on EI among students in the Administration course, which provides evidence to reject $\mathrm{H}_{1}$ : Gender positively influences the students' EI, as there was no such influence for students in the Executive Secretariat course, so shared cultural beliefs about gender stereotypes do not appear to shape the opportunities and incentives for respondents to invest in or perceive the entrepreneurial career as an option (Shinnar, Giacomin, \& Janssen, 2012).

Camelo-Ordaz, Diánez-González, and RuizNavarro (2016) have note that gender may not directly have an impact on EI. Wilson, Kickul, Marlino, Barbosa, and Griffiths (2009) and Shinnar, Giacomin, and Janssen (2012) have shown that the impact of perceptual factors in explaining differences in EI between men and women is limited and inconclusive, because being associated with culture, it is possible to perceive barriers to entrepreneurship and EI such as a lack of institutional support and skills, as well as fear of failure.

Regarding entrepreneurial parents (at least one is an entrepreneur), a positive influence from the family context on the EI of university students appeared in both samples, and students of administration were four times more likely to have EI if they have entrepreneurial parents, while secretarial services students are twice as likely to have EI if they are the children of entrepreneurs. It does therefore seem that family context does exert a strong influence on the EI of these university students, which coincides with the non-rejection of $\mathrm{H}_{2}$ : entrepreneurial family members positively influence the EI of students in the Administration and Executive Secretariat courses. The family environment can favor aspects such as creativity and the self-perception of creative thoughts, which contribute to the predisposition of the individual to undertake entrepreneurial activities (Zampetakis \& Moustakis, 2006).

This result is aligned with TPB, and the influence of social and family pressure on the formation of EI and entrepreneurial behavior can be observed (Ajzen, 1991; De Leeuw, Valois, Ajzen, \& Schmidt, 2015; Liñán \& Chen, 2009), which further confirms the findings of Van Auken, Stephens, Fry, and Silva (2006), who pointed out that the decision to become an entrepreneur is often influenced by the culture and individual values promoted through family and social referents.

Regarding the sustainable behavioral constructs, it appears that concern with waste had a negative influence on EI among university students in the Administration course, but mobilization had a positive influence. For students in the Executive Secretariat course, boycotting via consumption had a negative influence on EI, but as this was an inverse variable - in which such boycotts are positive for the environment $-\mathrm{H}_{3}$ need not be rejected: Sustainable behavior has a positive influence on the EI of students in the Administration and Executive Secretariat courses, as some sort of sustainable behavior had a positive influence on EI for students in each course.

Based on the innovative behavioral constructs, appropriateness to originality and the preference for change had a positive influence on EI among Administration students, while for the 
Executive Secretariat students, preference for change had a positive influence on EI, which indicates the non-rejection of $\mathrm{H}_{4}$ : Innovative behavior exerts a positive influence on the EI of students in the Administration and Executive Secretariat courses; in both courses, the influence of the preference for change was marked, and this shows that students perceive they need the stimulus of frequent change, which reinforces the findings of Wurthmann (2014), Soomro and Shah (2015), and Kollmann, Stöckmann, Meves, and Kensbock (2017).

Table 9 summarizes the results in relation to the research hypotheses, considering the expected and observed values.

Table 9. Values expected and observed in hypotheses

\begin{tabular}{l|l|c}
\multicolumn{1}{c|}{ Hypotheses } & $\begin{array}{c}\text { Expected } \\
\text { Value }\end{array}$ & $\begin{array}{c}\text { Observed } \\
\text { Value }\end{array}$ \\
\hline $\begin{array}{l}\mathrm{H}_{1} \text { Gender positively } \\
\text { influences the EI of students } \\
\text { in the Administration and }\end{array}$ & gender $\rightarrow$ EI & rejects \\
Executive Secretariat courses. & \\
\hline $\mathrm{H}_{2}:$ Entrepreneurial relatives \\
positively influence the EI of \\
students in the Administration \\
$\begin{array}{l}\text { and Executive Secretariat } \\
\text { courses. }\end{array}$ & $\begin{array}{l}\text { Entrepreneur } \\
\text { ial relatives } \\
\rightarrow \text { EI }\end{array}$ & $\begin{array}{c}\text { non- } \\
\text { rejects }\end{array}$ \\
\hline $\begin{array}{l}\mathrm{H}_{3}: \text { Sustainable behavior } \\
\text { exerts a positive influence on } \\
\text { the EI of students in the }\end{array}$ & $\begin{array}{l}\text { sustainable } \\
\text { behavior } \rightarrow\end{array}$ & $\begin{array}{c}\text { non- } \\
\text { rejects }\end{array}$ \\
$\begin{array}{l}\text { Administration and Executive } \\
\text { Secretariat courses. }\end{array}$ & EI & \\
\hline $\begin{array}{l}\mathrm{H}_{4}: \text { Innovative behavior has a } \\
\text { positive influence on the EI of } \\
\text { students in the Administration } \\
\text { and Executive Secretariat } \\
\text { courses. }\end{array}$ & $\begin{array}{l}\text { Innovative } \\
\text { behavior } \rightarrow\end{array}$ & $\begin{array}{c}\text { non- } \\
\text { rejects }\end{array}$ \\
\hline
\end{tabular}

Source: Prepared by the authors (2019).

$\rightarrow$ Positive Influence

In general, these results allow a better understanding of the influence of the sustainable and innovative behavioral constructs, as well as of gender and entrepreneurial family members on the EI of university students in Administration and Executive Secretariat courses. These results help overcome the literature gap that aligns sustainability and innovation to entrepreneurship, especially when considering EI as the main phenomenon to explain the process of entrepreneurship.

\section{Conclusion}

This study analyzed the influence of sustainable and innovative behavioral constructs on the EI of university students in Administration and Executive Secretariat courses. We also sought to investigate the influence of gender and family entrepreneurs on EI. The applied methodology was pertinent to meet the research objective, concentrating on logistic regression models for the courses investigated, which revealed important conclusions for the field of scientific knowledge, aligning entrepreneurship, innovation, and sustainability.

The results indicate that the sustainable and innovative behavioral constructs have a positive influence on the EI of university students in the Administration course, especially considering the constructs: mobilization, appropriateness to originality, and preference for change. Such students tend to think "outside the box," finding solutions in seemingly dead-end situations, and have a preference for frequent change, not just thinking about doing things better, but differently. These characteristics, in turn, are more likely to manifest in EI. Men were more also likely to have EI than women for students in this course.

When considering the students in the Executive Secretariat course, sustainable and innovative behavioral constructs also had a positive influence on EI, taking into account the boycott via consumption (inverse variable) and the preference for change, which verified that the students who worried about not buying products from companies that pollute the environment and those who prefer clear changes are more prone to EI.

The presence of familiar entrepreneurs also had a strong influence on the EI of university students in both courses, coinciding with the perspective of TPB (Ajzen, 1991) on the influence of social norms - in the familiar context-as a predictor of EI. The greatest influence was for business students: when they have entrepreneurial parents, their chances of having EI are four times higher than those who do not have entrepreneurial parents, while those in the Executive Secretariat course are twice as likely to have IE when they are the children of enterprising parents. In general, the influence of the family context on university students' EI was strongly identified in both courses related to management.

\section{Implications and Further Research}

Revista de Negócios, v. 24, n. 3, p. 7-26, July, 2019. 
This study contributes to the empirical and conceptual literature on entrepreneurship, especially because it allows the alignment between sustainability and innovation on the EI of university students in courses related to management, such as Administration and Executive Secretarial courses. This directly affects the construction of scientific knowledge on these phenomena, thus conferring an innovative perspective for the study.

Considering the current difficulties, such as numerous economic, social, and environmental crises, entrepreneurship is an alternative for people entering the world of work. As EI is relevant today, this study hopes to encourage the promotion of policies and practices directed at HEIs, with the expectation that HEIs can incorporate environmental, innovative, and social studies and practices in line with entrepreneurship to enhance the social and environmental benefits generated by entrepreneurs, which can in turn provide employment and income for society as a whole.

This research has a few limitations. The first is that only two courses related to management were considered, and the student population was limited to a university in the Brazilian Northeast, which may limit the generalizability of the findings. We also did not conduct in-depth interviews with the students, which would be necessary to have a more interpretative and qualitative perspective on the investigated phenomena.

Future studies to align sustainability and innovation with EI should consider other courses, such as Engineering, as well as including students from other universities or countries using the same model adopted in this study. This would help further expand our understanding of the alignment between sustainability and innovation in the presence of EI.

\section{References}

Ahmed, I., Nawaz, M. M., Ahmad, Z., Shaukat, M. Z., Usman, A., Rehman, W. U., \& Ahmed, N. (2010). Determinants of students' entrepreneurial career intentions: Evidence from business graduates. European Journal of Social Sciences, 15(2), 14-22.

Ajzen, I. (1991). The theory of planned behavior. Organizational behavior and human decision processes, 50(2), 179-211.

Ali, A., Topping, K. J., \& Tariq, R. H. (2010). Entrepreneurial Attributes among Postgraduate Students of a Pakistani University. Online Submission, 7(5), 66-77.

Armstrong, S. J., \& Hird, A. (2009). Cognitive style and entrepreneurial drive of new and mature business owner-managers. Journal of Business Psychology, 24(4), 419-430.

Arregle, J. L., Batjargal, B., Hitt, M. A., Webb, J. W., Miller, T., \& Tsui, A. S. (2015). Family ties in entrepreneurs' social networks and new venture growth. Entrepreneurship Theory and Practice, 39(2), 313-344.

Arshad, M., Farooq, O., Sultana, N., \& Farooq, M. (2016). Determinants of individuals' entrepreneurial intentions: a gender-comparative study. Career Development International, 21(4), 318-339.

Autio, E., H. Keeley, R., Klofsten, M., GC Parker, G., \& Hay, M. (2001). Entrepreneurial intent among students in Scandinavia and in the USA. Enterprise and Innovation Management Studies, 2(2), 145-160.

Barbosa, S. M. C., \& Durante, D. G. (2013). Secretariado Executivo e empreendedorismo: realidade ou utopia? Revista de Gestão e Secretariado, 4(1), 56-74.

Barbosa, S. D., Gerhardt, M. W., \& Kickul, J. R. (2007). The role of cognitive style and risk preference on entrepreneurial self-efficacy and entrepreneurial intentions. Journal of Leadership and Organizational Studies, 13(4), 86-104.

Baron, R., \& Shane, S. (2007). Entrepreneurship: a process perspective. Toronto: Nelson Education.

Bergmann, H., Hundt, C., \& Sternberg, R. (2016). What makes student entrepreneurs? On the relevance (and irrelevance) of the university and the regional context for student start-ups. Small Business Economics, 47(1), 53-76.

Birchler, A. E., \& Teixeira, A. (2017). A intenção empreendedora de estudantes e os fatores que a

Revista de Negócios, v. 24, n. 3, p. 7-26, July, 2019. 
influenciam. Revista de Negócios, 22(2), 7-22.

Boszczowski, A. K., \& Teixeira, R. M. (2012). O empreendedorismo sustentável e o processo empreendedor: em busca de oportunidades de novos negócios como solução para problemas sociais e ambientais. Revista Economia \& Gestão, 12(29), 141-168.

Bratt, C. (1999). The impact of norms and assumed consequences on recycling behavior. Environment and Behavior, 31(5), 630-656.

Brenner, O. C. (1982). Relationship of education to sex, managerial status, and the managerial stereotype. Journal of Applied Psychology, 67(3), 380-383.

Bruin, A., Brush, C. G., \& Welter, F. (2007). Advancing a framework for coherent research on women's entrepreneurship. Entrepreneurship Theory and Practice, 31(3), 323-339.

Camelo-Ordaz, C., Diánez-González, J. P., \& Ruiz-Navarro, J. (2016). The influence of gender on entrepreneurial intention: The mediating role of perceptual factors. BRQ Business Research Quarterly, 19(4), 261-277.

Camozzato, E. S., Serafim, F. K., Cavalheiro, C. C. M., Lizote, S. A., \& Verdinelli, M. A. (2018). Estilo cognitivo e intenção empreendedora dos estudantes de administração. Revista Gestão Universitária na América Latina-GUAL, 11(3), 105-121.

Cañizares, S. M. S. \& Garcia, F. J. F. (2010). Gender differences in entrepreneurial attitude. Equality, Diversity and Inclusion: An International Journal, 29, 766-786.

Cantner, U., Goethner, M., \& Silbereisen, R. K. (2017). Schumpeter's entrepreneur-A rare case. Journal of Evolutionary Economics, 27(1), 187214.

Carland, J. W., Hoy, F., Boulton, W. R., \& Carland, J. A. C. (2007). Differentiating entrepreneurs from small business owners: A conceptualization. In: Entrepreneurship (pp. 7381). Springer, Berlin, Heidelberg.
Carvalho, P. M. R. D., \& González, L. (2006). Modelo explicativo sobre a intenção empreendedora. Comportamento Organizacional e Gestão, 12(1), 43-65.

Ching, H. Y., \& Kitahara, J. R. (2015). Propensão a empreender: uma investigação quantitativa baseada nas características empreendedoras de alunos do curso de administração. Revista de Ciências da Administração, 1(1), 99-111.

Collis, J., \& Hussey, R. (2005). Pesquisa em administração: um guia prático para alunos de graduação e pós-graduação. Bookman.

Cooper, D. R., \& Schindler, P. S. (2011). Métodos de pesquisa em Administração. (10a. ed.) Porto Alegre: 2011.

Corral-Verdugo, V. (2012). The positive psychology of sustainability. Environment, Development and Sustainability, 14(5), 651-666.

Corral-Verdugo, V., \& Pinheiro, J. Q. (1999). Condições para o estudo do comportamento próambiental. Estudos de Psicologia, 4(1), 7-22.

Cruz, B. D. P. A., \& Botelho, D. (2016). Influenciadores da Percepção de Eficácia do Boicote e Intenção de Boicotar. Revista Pensamento Contemporâneo em Administração, 10(4), 99-113.

Damanpour, F. (1991). Organizational innovation: A meta-analysis of effects of determinants and moderators. Academy of management journal, 34(3), 555-590.

De Wit, G., \& Van Winden, F. A. (1989). An empirical analysis of self-employment in the Netherlands. Small Business Economics, 1(4), 263-272.

De Leeuw, A., Valois, P., Ajzen, I., \& Schmidt, P. (2015). Using the theory of planned behavior to identify key beliefs underlying pro-environmental behavior in high-school students: Implications for educational interventions. Journal of Environmental Psychology, 42, 128-138.

Delmar, F., \& Davidsson, P. (2000). Where do they come from? Prevalence and characteristics of nascent entrepreneurs. Entrepreneurship \&

Revista de Negócios, v. 24, n. 3, p. 7-26, July, 2019. 
regional development, 12(1), 1-23.

Elkington, J. (1997). Cannibals with forks: The triple bottom line of twentieth century business. Capstone: Oxford.

Elkington, J. (2013). Enter the triple bottom line. In: The triple bottom line (pp. 23-38). Routledge.

Esfandiar, K., Sharifi-Tehrani, M., Pratt, S., \& Altinay, L. (2019). Understanding entrepreneurial intentions: A developed integrated structural model approach. Journal of Business Research, 94, 172-182.

European Commission. (2013). Commnication from the commission to the European parliament, the council, the European economic and social committee and the committee of the regions. Emtrepreneurship 2020. Action Plan.

Fayolle, A., \& Gailly, B. (2015). The impact of entrepreneurship education on entrepreneurial attitudes and intention: Hysteresis and persistence. Journal of Small Business Management, 53(1), 75-93.

Fayolle, A., \& Liñán, F. (2014). The future of research on entrepreneurial intentions. Journal of Business Research, 67(5), 663-666.

Fischer, D., Mauer, R., \& Brettel, M. (2018). Regulatory focus theory and sustainable entrepreneurship. International Journal of Entrepreneurial Behavior \& Research, 24(2), 408-428.

Font, X., Garay, L., \& Jones, S. (2016).

Sustainability motivations and practices in small tourism enterprises in European protected areas. Journal of Cleaner production, 137, 1439-1448.

Foxall, G. R., \& Hackett, P. M. (1992). The factor structure and construct validity of the Kirton Adaption-Innovation Inventory. Personality and Individual Differences, 13(9), 967-975.

Gonçalves-Dias, S. L. F., Teodósio, A. D. S. D. S., Carvalho, S., \& Silva, H. M. R. D. (2009). Consciência ambiental: um estudo exploratório sobre suas implicações para o ensino de administração. RAE-eletrônica, 8(1), 1-22.
Günther, H., Pinheiro, J. Q., \& Guzzo, R. S. L. (2004). Psicologia Ambiental: entendendo as relações do homem com seu ambiente. Campinas: Alínea.

Gürol, Y., \& Atsan, N. (2006). Entrepreneurial characteristics amongst university students: Some insights for entrepreneurship education and training in Turkey. Education + Training, 48(1), 25-38.

Hair, J. F., Black, W. C., Babin, B. J., Anderson, R. E., \& Tatham, R. L. (2009). Análise multivariada de dados. Bookman Editora.

Hallam, C., Zanella, G., Dorantes Dosamantes, C. A., \& Cardenas, C. (2016). Measuring entrepreneurial intent? Temporal construal theory shows it depends on your timing. International Journal of Entrepreneurial Behavior \& Research, 22(5), 671-697.

Hindle, K., Klyver, K., \& Jennings, D. F. (2009). An "informed" intent model: Incorporating human capital, social capital, and gender variables into the theoretical model of entrepreneurial intentions. In Understanding the entrepreneurial mind (pp. 35-50). Springer, New York, NY.

Hughes, K. D., Jennings, J. E., Brush, C., Carter, S., \& Welter, F. (2012). Extending women's entrepreneurship research in new directions. Entrepreneurship Theory and Practice, 36(3), 429-442.

Hutchison, E. D. (2018). Dimensions of human behavior: The changing life course. Sage Publications.

Hutchinson, L. R., \& Skinner, N. F. (2007). Selfawareness and cognitive style: Relationships among adaption-innovation, self-monitoring, and self-consciousness. Social Behavior and Personality: an International journal, 35(4), 551560.

Kaiser, F. G., Doka, G., Hofstetter, P., \& Ranney, M. A. (2003). Ecological behavior and its environmental consequences: A life cycle assessment of a self-report measure. Journal of Environmental Psychology, 23(1), 11-20. 
Kickul, J., Gundry, L. K., Barbosa, S. D., \& Whitcanack, L. (2009). Intuition Versus Analysis? Testing Differential Models of Cognitive style on Entrepreneurial self-efficacy and the new venture creation process. Entrepreneurship theory and practice, 33(2), 439-453.

Kirton, M. (1976). Adaptors and innovators: A description and measure. Journal of Applied Psychology, 61(5), 622-629.

Kirton, M. J. (1984). Adaptors and innovatorsWhy new initiatives get blocked. Long range planning, 17(2), 137-143.

Kollmann, T., Stöckmann, C., Meves, Y., \& Kensbock, J. M. (2017). When members of entrepreneurial teams differ: linking diversity in individual-level entrepreneurial orientation to team performance. Small Business Economics, 48(4), 843-859.

Khuong, M. N., \& An, N. H. (2016). The factors affecting entrepreneurial intention of the students of Vietnam national university - a mediation analysis of perception toward entrepreneurship. Journal of Economics, Business and Management, 4(2), 104-111.

Krueger, N. F., \& Carsrud, A. L. (1993).

Entrepreneurial intentions: applying the theory of planned behaviour. Entrepreneurship \& Regional Development, 5(4), 315-330.

Krueger, N. F., Reilly, M. D., \& Carsrud, A. L. (2000). Competing models of entrepreneurial intentions. Journal of business venturing, 15(5-6), 411-432.

Kuckertz, A., \& Wagner, M. (2010). The influence of sustainability orientation on entrepreneurial intentions-Investigating the role of business experience. Journal of Business Venturing, 25(5), 524-539.

Lewis, P. (2006). The quest for invisibility: Female entrepreneurs and the masculine norm of entrepreneurship. Gender, Work \& Organization, 13(5), 453-469.

Liñán, F., \& Chen, Y. W. (2009). Development and Cross-Cultural application of a specific instrument to measure entrepreneurial intentions. Entrepreneurship Theory and Practice, 33(3), 593-617.

Liñán, F., \& Fayolle, A. (2015). A systematic literature review on entrepreneurial intentions: citation, thematic analyses, and research agenda. International Entrepreneurship and Management Journal, 11(4), 907-933.

Loiola, E., Gondim, S. M. G., Pereira, C. R., \& Ferreira, A. S. M. (2016). Ação planejada e intenção empreendedora entre universitários: analisando preditores e mediadores. Revista Psicologia Organizações e Trabalho, 16(1), 2235 .

Lumpkin, G. T., \& Dess, G. G. (1996). Clarifying the entrepreneurial orientation construct and linking it to performance. Academy of management Review, 21(1), 135-172.

Lüthje, C., \& Franke, N. (2003). The 'making' of an entrepreneur: testing a model of entrepreneurial intent among engineering students at MIT. $R \& D$ Management, 33(2), 135-147.

Marcati, A., Guido, G., \& Peluso, A. M. (2008). The role of SME entrepreneurs' innovativeness and personality in the adoption of innovations. Research Policy, 37(9), 1579-1590.

Martins, F. S., Santos, E. B. A., \& Silveira, A. (2019). Intenção Empreendedora: Categorização, Classificação de Construtos e Proposição de Modelo. Brazilian Business Review, 16(1), 46-62.

Minton, E. A., Spielmann, N., Kahle, L. R., \& Kim, C. H. (2018). The subjective norms of sustainable consumption: A cross-cultural exploration. Journal of Business Research, 82, 400-408.

Mirjana, P. B., Ana, A., \& Marjana, M. (2018). Examining determinants of entrepreneurial intentions in Slovenia: applying the theory of planned behaviour and an innovative cognitive style. Economic Research-Ekonomska Istraživanja, 31(1), 1453-1471.

Molaei, R., Reza Zali, M., Hasan Mobaraki, M., \& Yadollahi Farsi, J. (2014). The impact of

Revista de Negócios, v. 24, n. 3, p. 7-26, July, 2019. 
entrepreneurial ideas and cognitive style on students entrepreneurial intention. Journal of Entrepreneurship in Emerging Economies, 6(2), 140-162.

Moriano, J. A., Gorgievski, M., Laguna, M., Stephan, U., \& Zarafshani, K. (2012). A crosscultural approach to understanding entrepreneurial intention. Journal of career development, 39(2), 162-185.

Mueller, S. L., \& Dato-On, M. C. (2008). Genderrole orientation as a determinant of entrepreneurial self-efficacy. Journal of Developmental Entrepreneurship, 13(01), 3-20.

Mueller, S. L., \& Thomas, A. S. (2001). Culture and entrepreneurial potential: A nine country study of locus of control and innovativeness. Journal of business venturing, 16(1), 51-75.

Muñoz, P. (2018). A cognitive map of sustainable decision-making in entrepreneurship: A configurational approach. International Journal of Entrepreneurial Behavior \& Research, 24(3), 787-813.

Muñoz, P., \& Cohen, B. (2018). Sustainable entrepreneurship research: Taking stock and looking ahead. Business Strategy and the Environment, 27(3), 300-322.

Oliveira, B. M. F., Vieira, D., Laguía, A., Moriano, J. A., \& Soares, V. J. S. (2016). Intenção empreendedora em estudantes universitários: adaptação e validação de uma escala (QIE). Avaliaçao Psicologica, 15(2), 187-196.

Paiva, L. E. B., Bandeira, E. L., \& Soares, R. A. (2016). Aspectos comportamentais do empreendedorismo sustentável na intenção empreendedora dos estudantes universitários. In. Encontro da Associação Nacional de PósGraduação e Pesquisa em Administração, Costa do Sauípe, BA, 40, 2016.

Paiva, L. E. B., Lima, T. C. B., Rebouças, S. M. D. P., Ferreira, E. M. D. M., \& Fontenele, R. E. S. (2018). Influência da sustentabilidade e da inovação na intenção empreendedora de universitários brasileiros e portugueses. Cadernos EBAPE. BR, 16(4), 732-747.
Paço, A. M. F., Ferreira, J. M., Raposo, M., Rodrigues, R. G., \& Dinis, A. (2011). Behaviours and entrepreneurial intention: Empirical findings about secondary students. Journal of International Entrepreneurship, 9(1), 20-38.

Parrish, B. D. (2008). Sustainability-driven entrepreneurship: a literature review. University of Leeds, School of Earth \& Environment.

Pato, C. M. L., \& Tamayo, Á. (2006). A escala de comportamento ecológico: desenvolvimento e validação de um instrumento de medida. Estudos de Psicologia, 11(3), 289-296.

Pauceanu, A., Alpenidze, O., Edu, T., \& Zaharia, R. (2019). What determinants influence students to start their own business? empirical evidence from United Arab Emirates Universities. Sustainability, 11(1), 1-23.

Paul, J., Hermel, P., \& Srivatava, A. (2017). Entrepreneurial intentions - theory and evidence from Asia, America, and Europe. Journal of International Entrepreneurship, 15(3), 324-351.

Pereira, G. D. F., Cordeiro, A. T., Silva, M. A. P., \& Batista, M. M. (2013). Empreendedorismo regional: um olhar sobre a identidade cultural em narrativas locais. Revista de Negócios, 18(2), 326.

Randerson, K., Bettinelli, C., Fayolle, A., \& Anderson, A. (2015). Family entrepreneurship as a field of research: Exploring its contours and contents. Journal of Family Business Strategy, 6(3), 143-154.

Resolução n. 3, de 23 de junho de 2005 (2005). Institui as Diretrizes Curriculares Nacionais para o curso de graduação em Secretariado Executivo e dá outras providências. Brasília, DF. Recuperado em 06 maio 2019 de http://portal.mec.gov.br/cne/arquivos/pdf/rces003 _05.pdf

Rico, P., \& Cabrer-Borrás, B. (2018). Gender differences in self-employment in Spain. International Journal of Gender and Entrepreneurship, 10(1), 19-38.

Rodermund, E. S. (2004). Pathways to successful

Revista de Negócios, v. 24, n. 3, p. 7-26, July, 2019. 
entrepreneurship: Parenting, personality, early entrepreneurial competence, and interests. Journal of vocational behavior, 65(3), 498-518.

Santos, F. J., Roomi, M. A., \& Liñán, F. (2016). About gender differences and the social environment in the development of entrepreneurial intentions. Journal of Small Business Management, 54(1), 49-66.

Schlange, L. E. (2009). Stakeholder Identification in Sustainability Entrepreneurship. Greener Management International, 55, 13-32.

Schmidt, C. M., Monteiro, G. F. D. A., Hayashi, S., Tokuno, D., Marinho, B. D. L., \& Cielo, I. D. Perfil empreendedor: um estudo com acadêmicos de administração e secretariado executivo. Revista Expectativa, 7(7), 51-64.

Schmuck, P., \& Schultz, P. W. (2002).

Sustainable development as a challenge for psychology. In Psychology of sustainable development (pp. 3-17). Springer, Boston, MA.

Schröder, E., \& Schmitt-Rodermund, E. (2006). Crystallizing enterprising interests among adolescents through a career development program: The role of personality and family background. Journal of Vocational Behavior, 69(3), 494-509.

Schumpeter, J. A. (2017). Essays: on entrepreneurs, innovations, business cycles and the evolution of capitalism. Routledge.

Shane, S., Locke, E. A., \& Collins, C. J. (2003). Entrepreneurial motivation. Human resource management review, 13(2), 257-279.

Shapero, A. (1985). The entrepreneurial event. College of Administrative Science, Ohio State University.

Shapero, A., \& Sokol, L. (1982). The social dimensions of entrepreneurship.

Shinnar, R. S., Giacomin, O., \& Janssen, F. (2012). Entrepreneurial perceptions and intentions: The role of gender and culture. Entrepreneurship Theory and practice, 36(3), 465-493.
Sidanius, J. \& Pratto, F. (2001). Social dominance: An intergroup theory of social hierarchy and oppression, Cambridge University Press.

Sieger, P., \& Minola, T. (2017). The family's financial support as a "Poisoned gift": A family embeddedness perspective on entrepreneurial intentions. Journal of Small Business Management, 55(1), 179-204.

Silva, M. A., Gomes, L. F., \& Correia, M. (2009). Cultura e orientação empreendedora: uma pesquisa comparativa entre empreendedores em incubadoras no brasil e em Portugal. RAC-Revista de Administração Contemporânea, 13(1), 57-71.

Silveira, A., Backes, D. A. P., \& Kobayashi, A. R. K. (2017). Sustainable entrepreneurship: the scientific production of the 21st century. Revista de Negócios, 22(3), 22-37.

Soomro, B. A., \& Shah, N. (2015). Developing attitudes and intentions among potential entrepreneurs. Journal of Enterprise Information Management, 28(2), 304-322.

Straughan, R. D., \& Roberts, J. A. (1999). Environmental segmentation alternatives: a look at green consumer behavior in the new millennium. Journal of Consumer Marketing, 16(6), 558-575.

Solhi, S., \& Koshkaki, E. (2016). The antecedents of entrepreneurial innovative behavior in developing countries, a networked grounded theory approach (case study Iran). Journal of Entrepreneurship in Emerging Economies, 8(2), 225-262.

Stum, J. (2009). Kirton's adaption-innovation theory: managing cognitive styles in times of diversity and change. Emerging Leadership Journeys, 2(1), 66-78.

Subotic, M., Maric, M., Mitrovic, S., \& Mesko, M. (2018). Differences between adaptors and innovators in the context of entrepreneurial potential dimensions. Kybernetes, 47(7), 13631377.

Teixeira, A. A., \& Davey, T. (2010). Attitudes of

Revista de Negócios, v. 24, n. 3, p. 7-26, July, 2019. 
Higher Education students to new venture creation: a preliminary approach to the Portuguese case. Industry and Higher Education, 24(5), 323341.

Thomas, A. S., \& Mueller, S. L. (2000). A case for comparative entrepreneurship: Assessing the relevance of culture. Journal of International Business Studies, 31(2), 287-301.

Tilley, F., \& Parrish, B. D. (2009). Introduction. Greener Management International.

Turunç, Ö., Türköz, T., Akkoç, İ., \& Çalişkan, A. (2013). How do innovative and entrepreneurial behaviours affect the job performance? The moderating role of person-organisation fit. International Journal of Business Innovation and Research, 7(5), 590-618.

Van Auken, H., Stephens, P., Fry, F. L., \& Silva, J. (2006). Role model influences on entrepreneurial intentions: A comparison between USA and Mexico. The International

Entrepreneurship and Management Journal, 2(3), 325-336.

Van der Wal, A. J., Van Horen, F., \& Grinstein, A. (2018). Temporal myopia in sustainable behavior under uncertainty. International Journal of Research in Marketing, 35(3), 378-393.

Verheul, I., Wennekers, S., Audretsch, D., \& Thurik, R. (2001). An eclectic theory of entrepreneurship: policies, institutions and culture (No. 01-030/3). Tinbergen Institute Discussion Paper.

Walley, E. E., \& Taylor, D. W. (2002). Opportunists, champions, mavericks...? Greener Management International, 38, 31-43.

Wang, C. K., \& Wong, P. K. (2004). Entrepreneurial interest of university students in Singapore. Technovation, 24(2), 163-172.

Wang, D., Wang, L., \& Chen, L. (2018). Unlocking the influence of family business exposure on entrepreneurial intentions. International Entrepreneurship and Management Journal, 14(4), 951-974.
Wilson, F., Kickul, J., Marlino, D., Barbosa, S. D., \& Griffiths, M. D. (2009). An analysis of the role of gender and self-efficacy in developing female entrepreneurial interest and behavior. Journal of developmental Entrepreneurship, 14(2), 105-119.

Winn, J. (2005). Women entrepreneurs: can we remove the barriers? The International Entrepreneurship and Management Journal, 1(3), 381-397.

Wurthmann, K. (2014). Business students' attitudes toward innovation and intentions to start their own businesses. International Entrepreneurship and Management Journal, 10(4), 691-711.

Yusof, R., Imm, N. S., Ann, H. J., \& Rahman, A. A. (2018). The Influence of SMEs Employees' Intention towards Innovative Behaviour. Pertanika Journal of Social Sciences \& Humanities, 26(3), 1905-1923.

Zampetakis, L. A., \& Moustakis, V. (2006). Linking creativity with entrepreneurial intentions: A structural approach. The International Entrepreneurship and Management Journal, 2(3), 413-428.

Zampetakis, L. A., Bakatsaki, M., Litos, C., Kafetsios, K. G., \& Moustakis, V. (2017). Gender-based differential item functioning in the application of the theory of planned behavior for the study of entrepreneurial intentions. Frontiers in Psychology, 8, 451.

Zhang, P., Wang, D. D., \& Owen, C. L. (2015). A study of entrepreneurial intention of university students. Entrepreneurship Research Journal, 5(1), 61-82. 